\title{
C-kit negative extra intestinal gastrointestinal stromal tumor with no detectable mutations: A rare case
}

\author{
Asim Qureshi ${ }^{1}$, Shiyam Kumar ${ }^{2}$, Sinan I I smail ${ }^{3}$, Moza A Al Kalbani ${ }^{3}$, I kram A Burney² \\ 1. Pathology department, Sultan Qaboos university Hospital, Muscat, Oman. 2. Department of Medicine, Sultan Qaboos \\ university Hospital, Muscat, Oman. 3. Department of Molecular Imaging \& Radiology, Sultan Qaboos university Hospital, \\ Muscat, Oman.
}

Correspondence: Asim Qureshi. Address: Pathology department, Sultan Qaboos University hospital Muscat, Oman. Email: asimqureshi32@hotmail.com

Received: September 1, 2013

Accepted: September 26, 2013

Online Published: September 29, 2013

DOI : $10.5430 /$ jst.v3n5p25

URL: http://dx.doi.org/10.5430/jst.v3n5p25

\begin{abstract}
Epithelial tumors are quite common in the gastrointestinal tract, but in addition there is a heterogenous group of mesenchymal tumors which are referred to as Gastro-intestinal stromal tumors (GIST). These may have different morphology like epithelioid or spindle cell but have a common immunohistochemical profile. Majority of them are positive for CD117(Less than 5\% negative) those which are negative are almost always positive for DOG 1 antbody. These tumors are associated with the Gastro intestinal tract but a small percentage maybe extra-intestinal (less than 5\%) This small subgroup is referred to as EGIST (extra intestinal GIST). We present a rare case which was negative for CD 117, but positive for DOG1 (demonstrated on GIST). The case was tested for mutations and was also negative which makes it a further rarity.
\end{abstract}

\section{Key words}

Extra-intestinal GIST, CD117, Mutations

\section{I ntroduction}

Gastrointestinal stromal tumor (GIST) is one of the most common mesenchymal tumors of the gastrointestinal tract, accounting for $1-3 \%$ of all gastrointestinal malignancies (ESMO guidelines). GIST is characterized by mutation in the c-Kit or PDGFRA gene, and the vast majority (95\%) stain positively with CD117 antibody using immunohistochemistry (IHC), however, a small percentage are CD117 negative. Occasionally, GIST may arise outside of the gastro-intestinal tract (EGIST), and has been recognized as an uncommon variant. We present the rare case of an EGIST, negative for CD 117, but positive for DOG1 (demonstrated on GIST). The case presented as a diagnostic challenge.

\section{Case}

A 70-year-old post-menopausal woman was seen in the Gynecology clinic with one month history of increasing abdominal distension associated with anorexia, weight loss (more than $10 \mathrm{~kg}$ ) \& constipation. She developed urinary 
retention a day prior to presentation. There was no history of vaginal bleeding, vomiting, haematemesis or melena. The patient was a mother of one child, and there was no significant past medical or surgical history.

On examination, the patient was thin, weak and cachectic, deeply jaundiced and had no palpable lymph nodes. The chest was clear, except for basal crepitations on the left side. Abdominal wall was edematous, and there was a hard, non-tender fixed palpable mass arising from pelvis and reaching up to right upper quadrant. The mass had nodular surface, with appreciable margins. There was significant bilateral pedal edema, up to the calf muscles. Gynecological examination revealed a normal vulva, and atrophic vagina with minimal bleeding. The pelvic mass was felt to occupy whole pelvis, and the uterus and the adnexa could not be felt separately.

Laboratory investigations revealed normal hemoglobin $(11.3 \mathrm{~g} / \mathrm{dl}$, normal 11-14.5 g/dl), white cell count $(6.9 \times 109 / 1$, normal 2.4 - $9.5 \times 109 / 1)$, and platelets $(351 \times 109 / 1$, normal $150-450 \times 109 / 1)$. Her creatinine was mildly low $(43 \mu \mathrm{mol} / \mathrm{l}$, normal 45 - $84 \mu \mathrm{mol} / \mathrm{l})$ while liver functions revealed very high bilirubin $(328 \mu \mathrm{mol} / \mathrm{l}$, normal 0 - $17 \mu \mathrm{mol} / \mathrm{l})$, aspirate aminotransferase (109 U/1, normal 0 - $32 \mathrm{U} / 1$ ), alanine aminotransferase (42 U/1, normal 0 - $33 \mathrm{U} / 1$ ), alkaline phosphatase (574 U/l, normal 35 - $104 \mathrm{U} / \mathrm{l})$ and low albumin (20 g/l normal 34 - $48 \mathrm{~g} / \mathrm{l})$. Her tumor markers revealed high CA-125 (263 $\mathrm{KIU} / \mathrm{L}$, normal 0-35 KIU/L) and carcinoembryonic antigen $(2 \mu \mathrm{g} / 1$, normal - $3 \mu \mathrm{g} / \mathrm{l})$.

A CT scan of the chest and abdomen revealed cannon ball like solid lesions in both lungs, larger and multiple on the left side, a huge necrotic mass in the right lobe of the liver $(15 \mathrm{~cm} \times 12 \mathrm{~cm})$ sparing the left lobe of the liver, with mild dilatation of biliary tracts. There was a huge mass with dense focal calcifications, originating from the pelvic region, displacing the bowel loops as well as abdominal structures and compressing the retroperitoneal structures including spleen, and abutting the lower aspect of the liver showing degenerative internal changes, similar to the lesion in the liver.
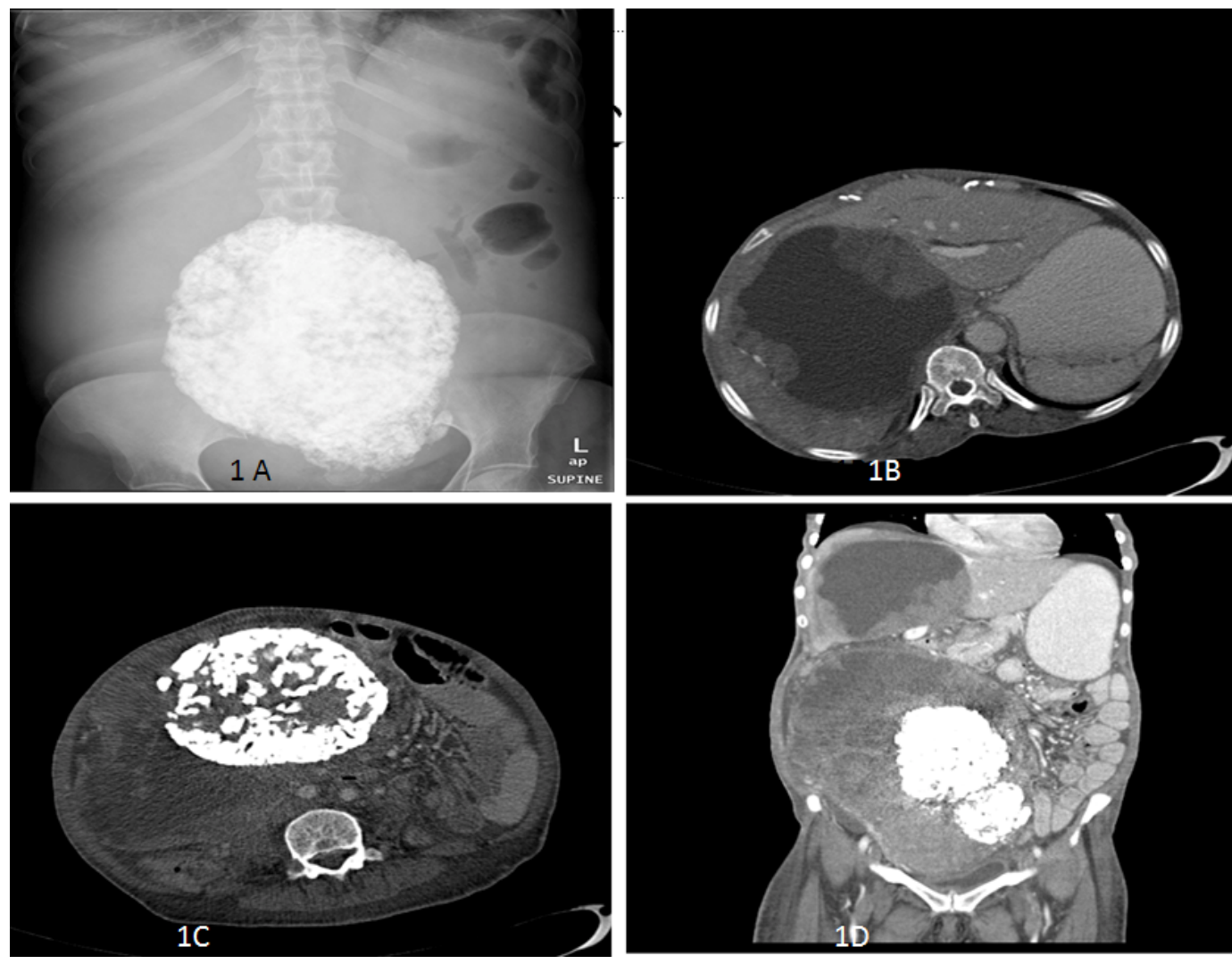

Figure 1. A. Radiological exam KUB. B. Axial Scan of liver. C. Axial Scan of liver. D. Coronal CT scan of abdomen 
KUB (Kidney urinary bladder) and CT axial slice of the abdomen showed a large complex mass occupying most of the right lobe of the liver with central degenerated area and marginal minimally enhanced solid compoent (Figure $1 \mathrm{~A}$ and 1B). $\mathrm{CT}$ and coronal reformat demonstrated a huge partially calcified mass extending from the pelvis to the subhepatic upper abdomen with biloculated calcified portion in its lower aspect (Figure $1 \mathrm{C}$ and $1 \mathrm{D}$ ).

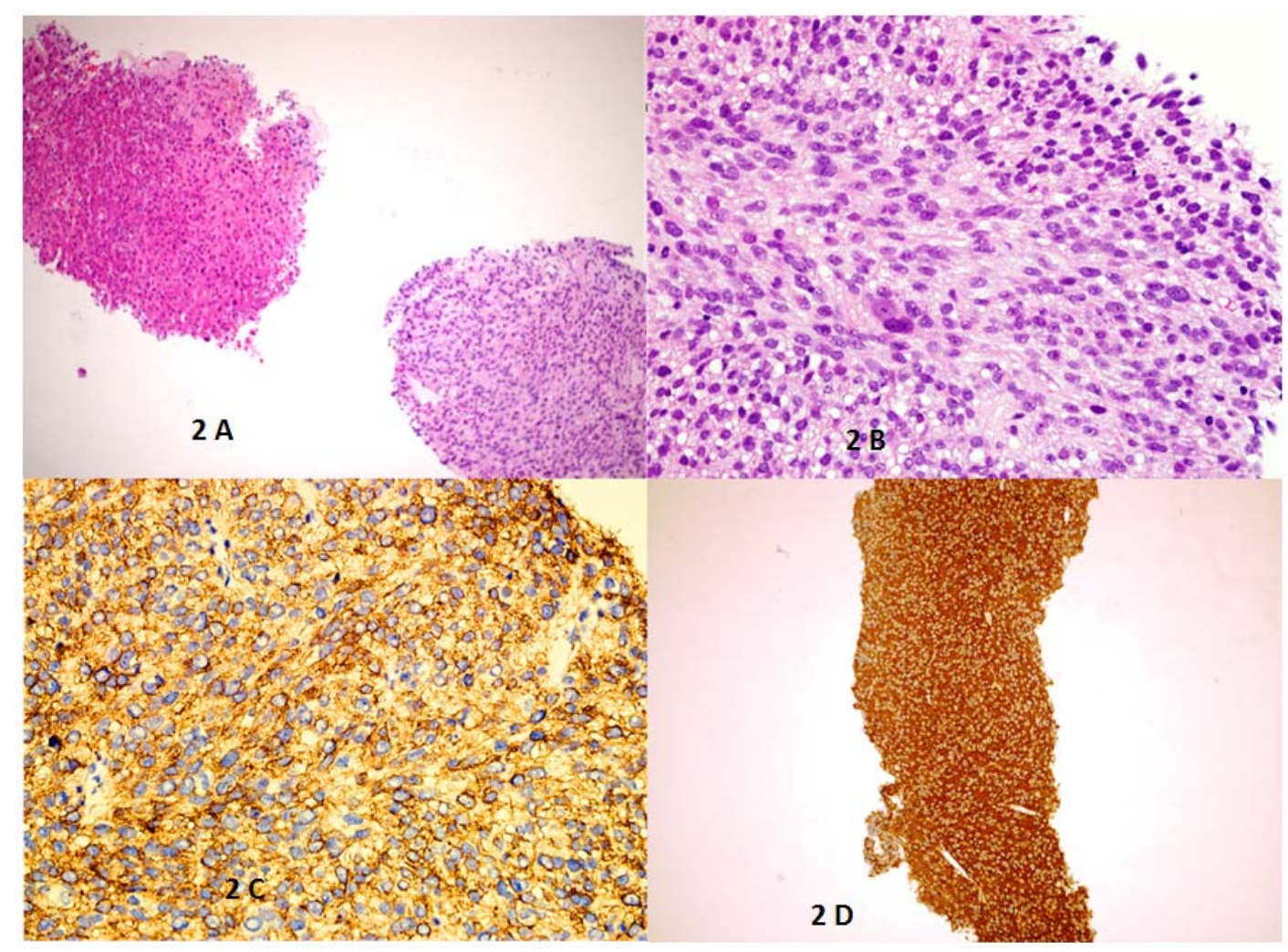

Figure 2. A. $\mathrm{H}$ and $\mathrm{E}$ section at $4 \mathrm{X}$ magnification. B. $\mathrm{H}$ and $\mathrm{E}$ section at $20 \mathrm{X}$ magnification. C. DOG 1 IHC stain. D. ASMA IHC stain

A trucut biopsy from the liver lesion showed a cellular spindle cell lesion, showing whorls and fascicles (Figure 2A). There was moderate nuclear atypia with brisk mitotic activity (Figure 2B) the mitotic rate was 10/10HPF. The tumor cells were negative for CD 34 and CD117 IHC stains and were strongly positive for DOG-1 and Anti Smooth Muscle Actin (anti-SMA) (Figure 2C, D). The morphology and IHC profile was consistent with CD 117 negative, DOG 1 positive GIST.As the tumor was strongly positive for smooth muscle actin it qualifies to be labelled as gist of smooth muscle differentiation. The tumor tissue was subjected to mutation analysis using polymerase chain reaction (PCR) and direct sequencing. The following exons were probed: exon 8, 9, 11,13, and 17 of the c-kit gene, and exons 12, 14, and 18 of the PDGFRA gene. No mutations were detected.

In view of poor condition and deranged liver functions, patient was deemed not fit for treatment, and was managed with terminal supportive care. Within 2 days of the diagnosis, oxygen saturation dropped, and the patient succumbed to progressive disease.

\section{Discussion}

GIST is the most common primary mesenchymal tumor of the GIT, and the vast majority $(>95 \%)$ have either c-kit or PDGFRA mutations ${ }^{[1]}$. However, the tumor could also arise from the extra-gastrointestinal sites. Fewer than $5 \%$ tumors 
may arise from sites, such as, the omentum, mesentery, and the peritoneum, and are called EGIST( extra gaxtra intestinal stromal tumors); omentum seems to be the commonest site ${ }^{[2-4]}$.

The tumors tend to occur in patients over the age of 50 years, epitheloid form is more common than the spindle cell form, the majority of tumors are large (more than $10 \mathrm{~cm}$ ), show tumor necrosis, nuclear atypia, a high Ki-67 labeling index, and a high mitotic count $(>10 / 50 \mathrm{HPF}){ }^{[5]}$. IHC features may create a diagnostic challenge. The tumors may be either negative or positive for c-kit (more than $95 \%$ of the GISTs are positive), but are usually positive for DOG1, protein kinase C (PKC) and CD34, vimentin, and PDGFRA ${ }^{[5,6]}$. Our patient was 70 years old, had a predominantly spindle cell form with smooth muscle differentiation. The tumor was $17 \mathrm{~cm}$ in the greatest dimension, and the mitotic count was 10/10 HPF, had areas of tumor necrosis as shown on the CT scan. The tumor was negative for CD117 (c-kit), but positive for CD34, anti-SMA and DOG1. Gastro intestinal tumors can show smooth muscle differentiaition as this tumor was positive for DOG 1, antibody which is only positive in tumors of this category thereby it was labelled as EGIST (with smooth muscle differntation). Whereas leiomyosarcomas are not positive for DOG 1.

c-kit negative GIST account for less than 5\% of all the GIST. For example, GIST arising from the stomach could also be negative for c-kit ${ }^{[7,8]}$. The tumors are usually epitheloid, and harbor mutations in the PDGFRA gene. However, c-kit negative tumors are more likely to be EGIST. DOG1 has emerged as a useful marker in EGIST ${ }^{[9]}$. DOG1 transcripts were identified in gene expression profiling studies on GISTs ${ }^{[10]}$. The corresponding protein with 8 transmembranous passes has been identified as a calcium-regulated chloride channel protein. Polyclonal and monoclonal antibody to DOG1 have superior sensitivity and specificity compared to KIT, and were found to label GISTs independent of KIT/PDGFRA mutation status ${ }^{[11,12]}$.

Because of the rarity of tumor, there are as yet no guidelines on the standard treatment of EGIST, hence, data need to be extrapolated from GIST. Recently, the European Organization for research and Treatment of Cancer (EORTC) have reported their results ${ }^{[9]}$. Between $5 \%$ and $7 \%$ of the patients with GIST harbored mutation in the PDGFRA gene, and 55\% had PDGFRA-D842V mutation, rendering them resistant to tyrosine kinase inhibitor, imatinib. This report necessitates that patients with EGIST should have the tumors analyzed for mutational status. The two largest series on EGIST were reported by Yamamoto et al $2004(\mathrm{n}=39)$, and Kim et al $2012(\mathrm{n}=28)$, demonstrating mutations on exon 11 of the c-kit gene and exon 18 of the PDGFRA gene in majority of cases. However, more than $95 \%$ of these EGISTs were c-kit positive on IHC. The only series of c-kit negative EGIST was published recently ${ }^{[13]}$. Out of a total of 10 patients, 9 had mutations, 7 on exon 12 and 1 on exon 18 of PDGFRA gene, and 1 on exon 11 of c-kit gene. Only one patient did not exhibit any mutation. Ours was a rare case of c-kit negative EGIST, with no detectable mutation in either the c-kit or the PDGFRA gene.

In conclusion, we report the case of a CD 117 negative, DOG 1 positive EGIST, with no detectable mutations, arising from the omentum. Since the tumors are rare, such cases should be reported for a subsequent detailed understanding.

\section{References}

[1] ESMO / European Sarcoma Network Working Group. Gastrointestinal stromal tumors: ESMO Clinical Practice Guidelines for diagnosis, treatment and follow-up. Ann Oncol. 2012 Oct; 23 Suppl 7:vii49-55. PMid:22997454 http://dx.doi.org/10.1093/annonc/mds252

[2] Todoroki T, Sano T, Sakurai S, Segawa A, Saitoh T, Fujikawa K, et al. Primary omental gastrointestinal stromal tumor (GIST). World J Surg Oncol. 2007 Jun 12; 5: 66. PMid:17565683 http://dx.doi.org/10.1186/1477-7819-5-66

[3] Matteo D, Dandolu V, Lembert L, Thomas RM, Chatwani AJ Unusually large extraintestinal GIST presenting as an abdomino-pelvic tumor. Arch Gynecol Obstet. 2008 Jul; 278(1): 89-92. PMid:18066563 http://dx.doi.org/10.1007/s00404-007-0528-9 
[4] Fagkrezos D, Touloumis Z, Giannila M, Penlidis C, Papaparaskeva K, Triantopoulou C Extra-gastrointestinal stromal tumor of the omentum: a rare case report and review of the literature. Rare Tumors. 2012 Jun 26; 4(3): e44. PMid:23087800 http://dx.doi.org/10.4081/rt.2012.e44

[5] Yamamoto H, Oda Y, Kawaguchi K, Nakamura N, Takahira T, Tamiya S, et al. c-kit and PDGFRA mutations in extragastrointestinal stromal tumor (gastrointestinal stromal tumor of the soft tissue). Am J Surg Pathol. 2004 Apr; 28(4): $479-88$. PMid:15087667 http://dx.doi.org/10.1097/00000478-200404000-00007

[6] Kim KH, Nelson SD, Kim DH, Choi KU, Kim SJ, Min KW, et al. Diagnostic relevance of overexpressions of PKC- $\theta$ and DOG-1 and KIT/PDGFRA gene mutations in extragastrointestinal stromal tumors: a Korean six-centers study of 28 cases. Anticancer Res. 2012 Mar; 32(3): 923-37. PMid:22399613

[7] Lee HE, Kim MA, Lee HS, Lee BL, Kim WH. Characteristics of KIT-negative gastrointestinal stromal tumours and diagnostic utility of protein kinase C theta immunostaining. J Clin Pathol. 2008 Jun; 61(6): 722-9. PMid:18381383 http://dx.doi.org/10.1136/jcp.2007.052225

[8] Rizzardi C, Marzinotto S, Avellini C, Melato M, Mariuzzi LA KIT-negative, DOG1-positive epithelioid GIST of the stomach harboring a novel PDGFRA exon 14 single nucleotide deletion. Anticancer Res. 2012 May; 32(5): 1775-8. PMid:22593460

[9] Cassier PA, Fumagalli E, Rutkowski P, Schöffski P, Van Glabbeke M, Debiec-Rychter M, et al; on behalf of European Organization for Research and Treatment of Cancer. Outcome of patients with platelet-derived growth factor receptor alpha-mutated gastrointestinal stromal tumors in the tyrosine kinase inhibitor era. Clin Cancer Res. 2012 Aug 15; 18(16): $4458-64$. PMid:22718859 http://dx.doi.org/10.1158/1078-0432.CCR-11-3025

[10] West RB, Corless CL, Chen X, Rubin BP, Subramanian S, Montgomery K, et al. The novel marker, DOG1, is expressed ubiquitously in gastrointestinal stromal tumors irrespective of KIT or PDGFRA mutation status. Am J Pathol. 2004; 165: 107-113. http://dx.doi.org/10.1016/S0002-9440(10)63279-8

[11] Caputo A, Caci E, Ferrera L, Pedemonte N, Barsanti C, Sondo E, et al. TMEM16A, a membrane protein associated with calcium-dependent chloride channel activity. Science. 2008; 322: 590-594. PMid:18772398 http://dx.doi.org/10.1126/science.1163518

[12] Espinosa I, Lee CH, Kim MK, Rous BT, Subramanian S, Montgomery K, et al. A novel monoclonal antibody against DOG1 is a sensitive and specific marker for gastrointestinal stromal tumors. Am J Surg Pathol. 2008, 32: 210-218. PMid:18223323 http://dx.doi.org/10.1097/PAS.0b013e3181238cec

[13] Yamamoto H, Kojima A, Nagata S, Tomita Y, Takahashi S, Oda Y. KIT-negative gastrointestinal stromal tumor of the abdominal soft tissue: a clinicopathologic and genetic study of 10 cases. Am J Surg Pathol. 2011 Sep; 35(9): 1287-95. PMid:21836495 http://dx.doi.org/10.1097/PAS.0b013e3182206f15 